\title{
Effects of a glass-ionomer cement on the remineralization of occlusal caries - an in situ study
}

\section{Efeito de um cimento de ionômero de vidro sobre a remineralização de cárie na superfície oclusal - estudo in situ}

\author{
Mônica Tostes Amaral* \\ Antônio Carlos Guedes-Pinto** \\ Orlando Chevitarese (in memorian)
}

\begin{abstract}
This work evaluated the remineralization of demineralized enamel of pits and fissures of human third molars sealed with a glass ionomer cement (Fuji IX, GC Corporation - Japan) or with a Bis-GMA sealant (Delton Dentsply). Ten volunteers participated in this in situ study that consisted of two thirty-day periods using intra-oral devices, with a week's interval in between. Four experimental treatment procedures and one control were randomly assigned to the volunteers' specimens: Group I, no treatment, control; Group II, artificial caries process; Group III, same treatment as Group II, but sealed with Delton (Dentsply); Group IV, same treatment as Group II, but sealed with Fuji IX (GC Corporation - Japan); Group V, same treatment as Group II and no sealing. Groups I and II were not submitted to the oral environment and served as controls. After a period of 30 days in the oral environment, the specimens were removed from the devices, embedded in acrylic resin, ground flat and polished. Then, Knoop hardness tests were performed, with a $25 \mathrm{~g}$ static load applied for 15 seconds. The measurements were made from the base of the fissure up to an opening of $600 \mu \mathrm{m}$, pre-established between the inclines of the cusps. Three indentations were then made, located at 25, 75, and $125 \mu \mathrm{m}$ in depth from the outer enamel margin and $100 \mu \mathrm{m}$ apart from each other (Micromet 2003). The Brieger F and Bonferroni's tests were applied to the measurements. It was concluded that sealing with the glass ionomer cement Fuji IX was capable of making the enamel of pits and fissures more resistant by increasing the value of Knoop hardness.
\end{abstract}

DESCRIPTORS: Glass ionomer cements; Dental enamel; Hardness.

\begin{abstract}
RESUMO: Esta pesquisa avaliou a remineralização do esmalte de fóssulas e fissuras de terceiros molares humanos previamente desmineralizados e selados com um cimento de ionômero de vidro (Fuji IX, GC Corporation - Japão) ou com um selante de Bis-GMA (Delton-Dentsply). Dez voluntários participaram deste estudo in situ que consistiu de dois períodos de 30 dias com intervalo de 1 semana entre eles, usando dispositivos intra-orais. Quatro procedimentos de tratamento experimental e um controle foram aleatoriamente distribuídos entre os espécimes que foram usados pelos voluntários: Grupo I, sem qualquer tratamento, controle; Grupo II, processo de cárie artificial; Grupo III, igual ao Grupo II, porém selados com Delton (Dentsply); Grupo IV, igual ao Grupo II, porém selados com Fuji IX (GC Corporation - Japão); Grupo V, igual ao Grupo II, mas sem selamento. Os Grupos I e II não foram submetidos ao meio bucal e serviram de controle. Após um periodo de trinta dias no meio bucal, os espécimes foram removidos dos dispositivos, montados em resina acrilica, planificados e polidos. Realizaram-se então testes de Dureza Knoop com carga estática de 25 g por 15 segundos. As medidas foram realizadas desde a base da fissura até uma abertura de $600 \mu \mathrm{m}$, preestabelecida entre os planos inclinados das cúspides. A cada $100 \mu \mathrm{m}$, três penetrações foram realizadas: a primeira a $25 \mu \mathrm{m}$ da superficie da fissura, a segunda a $75 \mu \mathrm{m}$, e a terceira a $125 \mu \mathrm{m}$ (Micromet 2003). Os dados obtidos foram analisados estatisticamente pelos testes "F" de Brieger e de Bonferroni. Concluiu-se que o selamento com o cimento de ionômero de vidro Fuji IX foi capaz de tornar o esmalte de sulcos e fissuras mais resistente pelo aumento do valor de dureza Knoop.
\end{abstract}

DESCRITORES: Cimentos de ionômeros de vidro; Esmalte dentário; Dureza.

\section{INTRODUCTION}

Pit and fissure sealants are recommended for permanent and primary teeth that have risk of developing dental caries ${ }^{2,13,16}$. Bravo et al. ${ }^{2}$ (1996) observed that children with high dental caries inci- dence had a lower degree of resin sealant retention. This occurrence suggests that the use of resin sealants in Public Health Programs requires a greater number of dental visits in order to check and reap-

\footnotetext{
* Professor, Department of Pediatric Dentistry, School of Dentistry, Federal University of Rio de Janeiro.

** PhD, Professor, Department of Pediatric Dentistry, School of Dentistry, University of São Paulo.
} 
Amaral MT, Guedes-Pinto AC, Chevitarese O. Effects of a glass-ionomer cement on the remineralization of occlusal caries - an in situ study. Braz Oral Res 2006;20(2):91-6.

ply the sealant, thus increasing the cost of the program. Studies that have evaluated the retention of glass ionomer cement used as sealant showed discrepant results, although all of them demonstrated that it was inferior to resin-based sealants ${ }^{9,22}$. The cariostatic effects of the glass ionomer material is due to its fluoride release $e^{8,11,12,25}$. Therefore, in relation to caries prevention, the loss of this material is of lesser importance and does not interfere with its effect, since scientific investigation has shown that the aim of these types of sealants is not exclusively to function as a mechanical barrier. In addition, there is the fact that some material may still remain in the pit and fissures ${ }^{19}$, despite the appearance of the sealant being lost.

Other facts to consider, when using sealants, are the incipient caries lesions on fissures and the difficulty of their adequate diagnosis ${ }^{17}$. The probable consequence of this is the inadvertent use of sealants on many caries lesions; yet, the use of resin sealant is not contraindicated in the presence of incipient caries lesions in regard to adhesion, as seen by van Dorp, ten Cate ${ }^{29}$ (1987), or to the arrest of the lesion, as observed by Mertz-Fairhurst et $a l .{ }^{20}$ (1998). This type of prevention mechanism has been greatly studied on smooth surfaces, but studies on the occlusal surface are scarce ${ }^{7,8,15}$.

A wide range of techniques have been used or especially developed to measure the changes occurring in the tissue. Among these are tests to quantify changes in physical properties, such as hardness, or to measure changes in the chemical composition ${ }^{5}$.

The aim of this study was to evaluate enamel remineralization at the margins of the fissures of human third molars sealed with a glass ionomer cement Fuji IX (GC Corporation, Tokyo - Japan) or with a Bis-GMA sealant (Delton - Dentsply), through Knoop's microhardness analysis.

\section{MATERIAL AND METHODS}

Figure 1 provides an overview of the experiment. This research project was submitted to and authorized by the Commitee of Ethical Aspects in Dental Research, School of Dentistry, University of São Paulo. This was an in situ crossover study consisting of two thirty-day periods with a week's interval in between. Ten volunteers were chosen to participate in the study according to the criterion of Featherstone, Zero ${ }^{6}$ (1992). The volunteers received intra-oral devices with demineralized enamel specimens of the occlusal surfaces of extracted human third molars. Four experimental treatment procedures and one control were randomly assigned to the volunteers' specimens. The experimental treatments were as follows:

- Group I - caries free control (sound). Samples without artificial caries lesions and maintained outside the mouth.

- Group II - artificial caries control. Samples with artificial caries lesions but with no sealant and maintained outside the mouth.

- Group III - samples with artificial caries lesion and sealed with Delton, placed in the intraoral device.

- Group IV - sample with artificial caries lesion sealed with Fuji IX, placed in the intra oral device.

- Group V - artificial caries control without sealant, samples with artificial caries lesions and no sealant, and placed in the intra-oral device.

Twenty extracted, sound third molars, with more than $2 / 3$ of root formation, were cleaned of gross debris and stored in a $1 \%$ solution of formaldehyde $(\mathrm{pH}=7)$ and maintained under refrigeration until they were used, approximately 3 months later. Samples of the occlusal surfaces measuring $1.5 \mathrm{~mm}$ in the mesiodistal direction and $4 \mathrm{~mm}$ in the buccolingual direction were obtained using a water-cooled diamond blade (Figure 1). The samples had an area of aproximately $6 \mathrm{~mm}^{2}$. All samples were stored in a humidifier for one week and cleaned with distilled water and pumice. From 12 third molars, four samples were obtained from each tooth, and from the remaining eigth teeth, five samples were obtained from each tooth, thus, producing a total of 88 samples. The samples were randomly divided among the five Groups mentioned previously. Groups I, II, III and IV had 20 samples each, and Group V had eight samples. This occurred because not always all third molars had five samples available. From some teeth, only four samples could be obtained, as described previously. For the artificial cariesfree group (Group I), one sample of each tooth was maintained at room temperature in the humid environment specified earlier. All other samples were submitted to the artificial caries process.

On the entire occlusal surface, except for $1 \mathrm{~mm}$ around the fissure, the samples were embedded with fast setting epoxy resin (Araldite, Ciba-Geizy Química S/A, São Paulo, Brazil). This procedure was performed with the aid of a compass and before initiating the artificial caries process. Every specimen was placed in a vessel with $10 \mathrm{ml}$ of a $0.1 \mathrm{M}$ lactic acid aqueous solution $(\mathrm{pH}=4.3)$ with $5 \%$ of methyl cellulose, at $37^{\circ} \mathrm{C}$, for seven weeks. At the end of the caries procedure, all samples 
Amaral MT, Guedes-Pinto AC, Chevitarese O. Effects of a glass-ionomer cement on the remineralization of occlusal caries - an in situ study. Braz Oral Res 2006;20(2):91-6.

were washed with distilled water and sterilized by exposure to ethylene oxide vapour for 12 hours before being sealed and placed into the intra-oral devices $^{3}$. The occlusal surfaces of the samples were sealed in the following manner:

a. Bis-GMA resin Group (Group III) - Delton (Dentsply) sealant was used in this group. The samples were cleaned with a polishing brush on a low-speed handpiece with pumice and water for 15 seconds and washed with water for 30 seconds. Manipulation and placement of the sealant were performed according to manufacturer's instructions.

b. Glass ionomer cement Group (Group IV) - The Fuji IX (GC Corporation, Tokyo - Japan) glass ionomer cement was used. It was placed with a dental probe and condensed with an amalgam packer. After the cement lost its shinny appearance, a varnish coat (Procosa Produtos de Beleza Ltda., SP, Brazil) was placed as recommended by the manufacturer. Establishment of the powder/liquid ratio and manipulation were also performed according to the manufacturer's instructions.

These two sealants were placed within the $1 \mathrm{~mm}$ limit established for artificial dental caries lesion. After the setting time of each material, the samples were immediately placed into the intraoral device and used by the volunteers.

Each volunteer used an intra-oral device with samples of two different teeth, but with the same sealant on both. For example, volunteer number one always used samples of teeth numbers one and two, both with the Fuji IX sealant (Group IV). On the second phase of the study, the same volunteer used samples of teeth one and two, but this time sealed with Delton (Group III). The volunteers only used samples of Group V when five samples were obtained from the teeth assigned. The volunteers were instructed not to brush the intra-oral device where the samples were placed, nor to take any type of medication containing fluoride, to use only fluoride-free toothpaste (starting one week before the study and through all the investigation period), to perform their oral hygiene as they usually did, use the intra-oral device 24 hours a day and to remove it only at meal times. The samples were removed at the end of the thirty-day period and cleaned with a $5 \%$ sodium hypochlorite solution for one hour. Afterwards, they were maintained in the humid environment described previously, for microhardness evaluation. Each specimen was then embedded in self-curing acrylic resin, in such a way that the area to be evaluated was exposed (Figure 1). The longitudinally cut surfaces (the

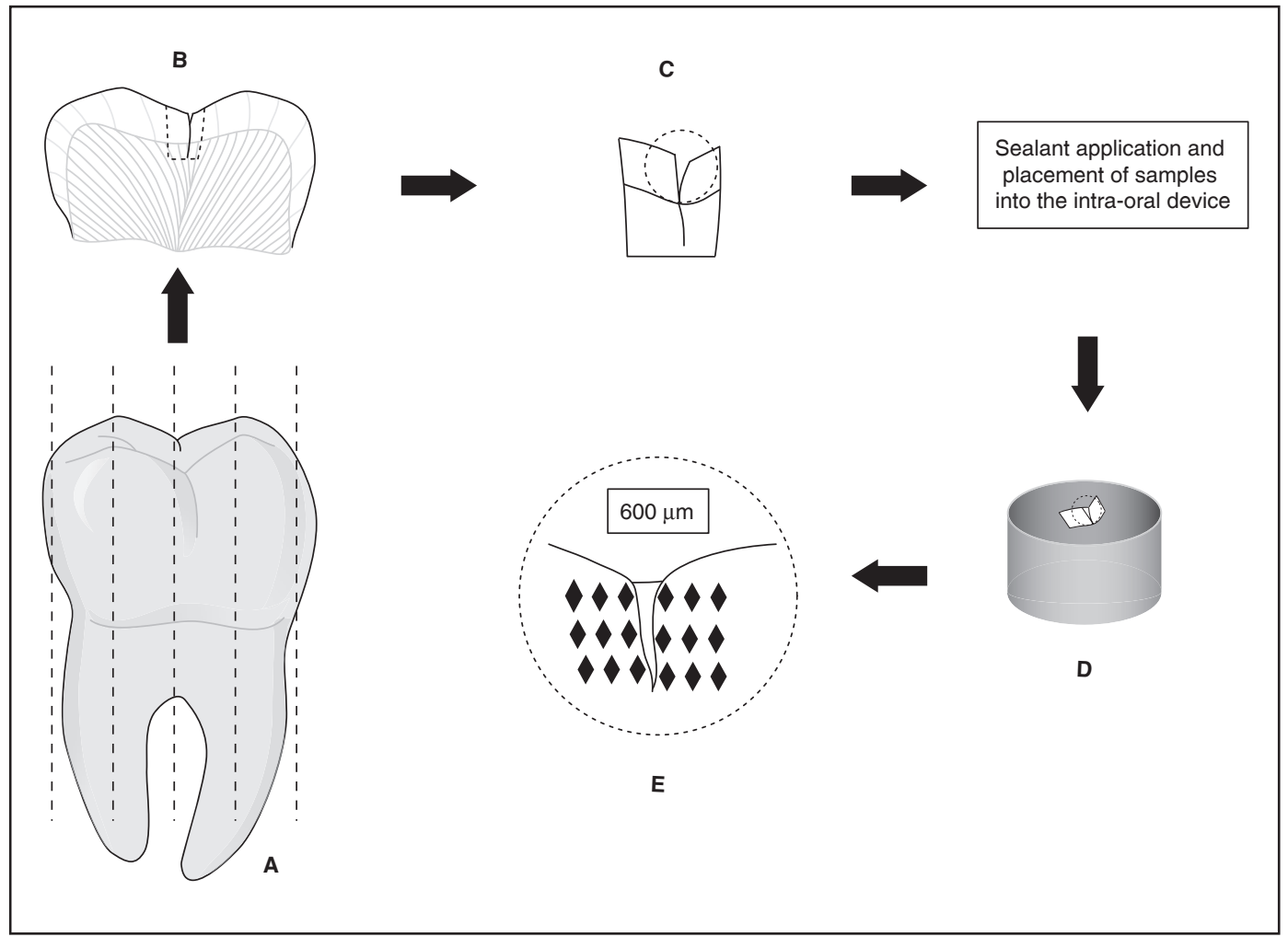

FIGURE 1 - Study design. A: slices of the tooth.

B: Sample of occlusal surface measuring $1.5 \times 4.0 \times 6.0 \mathrm{~mm}$ C: artificial caries. D: tooth fragment inserted in self-curing acrylic resin. E: Knoop indentations (enamel). 
Amaral MT, Guedes-Pinto AC, Chevitarese O. Effects of a glass-ionomer cement on the remineralization of occlusal caries - an in situ study. Braz Oral Res 2006;20(2):91-6.

areas to be evaluated) were serially polished on a polishing machine using 600 and 1,000 grade aluminum oxide paper under water, followed by $1 \mu \mathrm{m}$ alumina.

The inhibition of demineralization was quantified through microhardness analyses. Indentations were made with a microhardness tester (Micromet 2003, Buehler, Illinois, USA, fitted with a diamond Knoop penetrator - Buehler, Illinois, USA -, used for 15 seconds with a $25 \mathrm{~g}$ load). The indentations were made longitudinally along the fissure, starting at its base until the opening of $600 \mu \mathrm{m}$ and paralled to the surface (Figure 1). The indentations were made taking as reference the external wall of the fissure. The indentations were located at 25 (Line A), 75 (Line B) and $125 \mu \mathrm{m}$ (Line C) in depth from the outer enamel margin and were separated from each other by a distance of $100 \mu \mathrm{m}^{5,22}$.

The values obtained were converted to Knoop Hardness Number (KHN), written down and organized in a Table. To evaluate significant differences, Brieger $\mathrm{F}$ and Bonferroni's tests were applied to the measurements.

\section{RESULTS}

The microhardness values of lines A, B and C are presented in Table 1. Group IV (Fuji IX) showed the highest hardness mean value, which was statistically different from that of the other Groups at all distances tested, except for Group I (Control). In lines $\mathrm{B}$ and $\mathrm{C}$, the mean microhardness value of Group I was statistically different from that of Groups II, III and V, but not from that of Group IV. The lowest mean values were obtained in Groups II and V.

\section{DISCUSSION}

In this study, an increase in the mean Knoop microhardness at all distances tested (Lines A, B and C) was observed on the enamel surface adjacent to the glass ionomer cement, when compared to the enamel adjacent to the Delton sealant or in the control Group with no sealant (adjacent to saliva). These results suggest that the glass ionomer cement is capable of interfering with the progression of the artificial caries lesion when used as pit and fissure sealant in a distance up to $125 \mu \mathrm{m}$. However, it is important to consider the limitations of the evaluations performed.

Microhardness profile can be used not only as a comparative measure of hardness changes but as a direct measure of mineral gain or loss as a consequence of demineralization and presumably remineralization ${ }^{5}$.

The highest mineral loss was observed in Group II (control with artificial caries only), with a loss of $9.75 \%$ in line A, followed by Groups V and III. At the other lines, mineral loss was detected in all Groups, although in Group IV this loss was very low. These results are in agreement with those obtained by Seppä, Forss ${ }^{24}$ (1991), who observed a higher resistance to demineralization in fissures previously sealed with a glass ionomer cement, and Benelli et al. ${ }^{1}$ (1993) in smooth surfaces. Other studies have also observed a lesser degree of demineralization on the enamel adjacent to fluoride releasing material ${ }^{3,10,23}$. In the in vitro studies performed by Forss, Seppä ${ }^{10}$ (1989), the mean enamel hardness adjacent to the glass ionomer cement was lower than in the control Group, even in the presence of fluoride that had been released by this material; in other words, in all these investigations mentioned, there was mineral loss, although this loss was always lesser in the glass ionomer group.

These results are different from those found in our in situ study because mineral gain was detected in the GIC Group. This could be explained by two facts: first, the enamel used was decalcified

TABLE 1 - Knoop microhardness number mean values for lines A, B and C of groups I, II, III, IV and V.

\begin{tabular}{|c|c|c|c|c|c|c|c|}
\hline \multirow{2}{*}{ Groups } & \multirow{2}{*}{$\mathrm{N}$} & \multicolumn{3}{|c|}{ mean } & \multicolumn{3}{|c|}{ Standard deviation } \\
\hline & & A $-25 \mu \mathrm{m}$ & $\mathrm{B}-75 \mu \mathrm{m}$ & $\mathrm{C}-125 \mu \mathrm{m}$ & A & $\mathrm{B}$ & $\mathrm{C}$ \\
\hline I & 232 & $196.09^{\mathrm{abA}}$ & $249.00^{\mathrm{abc}}$ & $253.51^{\mathrm{abcA}}$ & 72.98 & 64.15 & 63.58 \\
\hline II & 231 & $137.76^{* a c d A}$ & $212.08 *$ adA & $230.99 *$ adA & 63.04 & 69.64 & 51.58 \\
\hline III & 215 & 173.41 *bceA & $226.15^{* \text { be }}$ & $229.72 *$ beA & 71.77 & 62.54 & 57.11 \\
\hline IV & 236 & $208.66^{* \operatorname{defA}}$ & $245.14 *$ def & $252.64 *$ defA & 76.88 & 60.00 & 54.50 \\
\hline V & 77 & $154.08^{* \mathrm{fA}}$ & $221.59 * \mathrm{cf}$ & $216.67 * \mathrm{cfA}$ & 68.17 & 56.36 & 62.16 \\
\hline
\end{tabular}

$\overline{\mathrm{p}<0.01-\text { The mean values of Group IV }\left(^{*}\right) \text { were statistically different in relation to the other Groups (*). The same superscript low- }}$ ercase letters (vertical lines) represent statistical difference between Groups. Capital letters represent difference between lines A, $\mathrm{B}$ and $\mathrm{C}$ for each group (Horizontal lines). 
Amaral MT, Guedes-Pinto AC, Chevitarese O. Effects of a glass-ionomer cement on the remineralization of occlusal caries - an in situ study. Braz Oral Res 2006;20(2):91-6.

and, therefore, could have facilitated fluoride gain as described by Koulourides et al. ${ }^{14}$ (1974); second, due to the in situ remineralization model used. The presence of fluoride in association to favorable remineralization conditions could have affected the results, since all volunteers had good oral hygiene and no sucrose solution or any other cariogenic methods were used on the samples. Furthermore, all samples were placed below the acrylic margin level of the intra-oral devices to allow plaque accumulation and to simulate what would happen in a child with an erupting tooth that is not adequately cleaned. Consequently, as mentioned by some authors ${ }^{21,26,28}$, the fluoride accumulated in the dental plaque (biofilm) and the decreased number of $S$. mutans and Lactobacillus gave rise to the remineralization of the artificial caries lesions. Some investigations have demonstrated and proven that along the GIC restorations there is a certain amount of bacterial inhibition ${ }^{21,25,28}$. Neither the concentration of released fluoride, nor how it was incorporated into the enamel was evaluated in this study. Other studies have shown that there is a fluoride increase on the enamel adjacent to GIC restorations $^{1,10}$. In Group III (Delton), an increase in the hardness mean was found only in line A, when compared to Group II (artificial caries control). This increase in hardness could be explained by tag formation in the external layer of the fissure wall, as shown by van Dorp, ten Cate ${ }^{29}$ (1987). In Group IV (Fuji IX), the highest microhardness mean was found in line A, near the external surface of the fissure wall; yet, at all distances tested, there was

\section{REFERENCES}

1. Benelli EM, Serra MC, Rodrigues AL Jr, Cury JA. In situ anticariogenic potential of glass ionomer cement. Caries Res 1993;27:280-4.

2. Bravo M, Osório E, Garcia-Anllo J, Llodra JC, Baca P. The influence of dft index on sealant success: a 48-month survival analysis. J Dent Res 1996;75:768-74.

3. Cain BE, Corpron RE, Fee CL, Strachan DS, Kowalski CJ. Dose related remineralization using intraoral fluoride-releasing devices in situ. Caries Res 1994;28:284-90.

4. Deery C, Fyffe HE, Nugent ZJ, Nuttall NM, Pitts NB. General dental practitioners diagnostic and treatment decisions related to fissure sealed surfaces. J Dent 2000;28:313-8.

5. Featherstone JDB, ten Cate JM, Shariati M, Arends J. Comparison of artificial caries-like lesions by quantitative microradiography and microhardness profiles. Caries Res 1983;17(5):385-91.

6. Featherstone JD, Zero DT. An in situ model for simultaneous assessment of inhibition of demineralization and enhancement of remineralization. J Dent Res 1992;71:80410 . an increase in microhardness when compared to Group II (artificial caries control). Similar results were found in smooth surfaces of in vitro studies that used fluoride releasing material ${ }^{4,10,12,27}$.

Another factor analysed was the Knoop mean microhardness at line A of Group I (caries-free control). A very low microhardness value was detected when compared to those found in smooth surfaces. The mean Knoop microhardness values found for smooth surfaces was 356.8 in erupted teeth ${ }^{23}$.

Marinelli et al. ${ }^{18}$ (1997) detected remineralization of caries lesions after a one month-period maintained in artificial saliva and fluoride. In Marinelli et al.'s ${ }^{18}$ (1997) study, the most effective methods for remineralization, in decreasing order, were $0.05 \%$ sodium fluoride solution, fluoridated toothpaste and a GIC. The control Group exposed only to saliva had the lowest remineralization degree. On the other hand, in our study, this remineralization effect was not observed, considering that the mean Knoop microhardness was not significantly greater than those found in Group II at all distances tested. This leads us to believe that the thirty-day period was not enough to completely remineralize the pit and fissure lesion.

\section{CONCLUSION}

The enamel of the fissure's margin showed mean microhardness greater in Group IV (Fuji IX) when compared to that of the other Groups. Therefore, the GIC was capable of remineralizing the margin of the fissure.

7. Forss H, Jokinen J, Spets-Happonen S, Seppä L, Luoma $\mathrm{H}$. Fluoride and mutans streptococci in plaque grown on glass ionomer and composite. Caries Res 1991;25:454-8.

8. Forss H, Näse L, Seppä L. Fluoride concentration, mutans streptococci and lactobacilli in plaque from old glass ionomer fillings. Caries Res 1995;29:50-3.

9. Forss H, Saarni UM, Seppä L. Comparison of glass-ionomer and resin-based fissure selants: a 2-year clinical trial. Community Dent Oral Epidemiol 1994;22:21-4.

10. Forss H, Seppä L. Prevention of enamel demineralization adjacent to glass ionomer filling materials. Scand J Dent Res 1989;98:173-8.

11. Hattab FN, El-Mowafy OM, Salem NS, E1-Badrawy WA. An in vivo study on the release of fluoride from glassionomer cement. Quintessence Int 1991;22:221-4.

12. Hicks MJ, Flaitz CM. Caries formation in vitro around a fluoride-releasing pit and fissure sealant in primary teeth. J Dent Child 1998;65:161-8.

13. Karlzén-Reuterving G, van Dijken JW. A three-year follow-up of glass ionomer cement and resin fissure sealants. ASDC J Dent Child 1995;62:108-10. 
Amaral MT, Guedes-Pinto AC, Chevitarese O. Effects of a glass-ionomer cement on the remineralization of occlusal caries - an in situ study. Braz Oral Res 2006;20(2):91-6.

14. Koulourides T, Phantumvanit E, Munksgaard EC, Housch T. An intraoral model used for studies of fluoride incorporation in enamel. J Oral Pathol 1974;3:185-96.

15. Lagerweij MD, Damen JJM, ten Cate JM. Demineralization of dentin grooves in vitro. Caries Res 1996;30:231-6.

16. Locker D, Ivkovic A, Kay EI. Prevention. Part 8: The use of pit and fissure sealants in preventing caries in the permanent dentition of children. Br Dent J 2003;195:375-8.

17. Lussi A. Validity of diagnostic and treatment decisions of fissure caries without cavitation. Caries Res 1991;27:409-15.

18. Marinelli CB, Donly KJ, Wefel JS, Jakobsen JR, Denehy GE. An in vitro comparison of three fluoride regimens on enamel remineralization. Caries Res 1997;31:418-22.

19. Mejàre I, Mjör IA. Glass ionomer and resin-based fissure sealants: a clinical study. Scand J Dent Res 1990;98:345-50.

20. Mertz-Fairhurst EJ, Curtis JW Jr, Ergle JW, Rueggeberg FA, Adair SM. Ultraconservative and cariostatic sealed restorations: results at year 10. J Am Dent Assoc 1998;129:55-65.

21. Palenik CJ, Behnen MJ, Setcos JC, Miller CH. Inhibition of microbial adherence and growth by various glass ionomers in vitro. Dent Mater 1992;8:16-20.

22. Selwistz RH, Nowjack-Raymer R, Driscoll WS, Li SH. Evaluation after 4 years of the combined use of fluoride and dental sealants. Community Dent Oral Epidemiol 1995;23:30-5.

23. Serra MC, Cury JA. The in vitro effect of glass-ionomer cement restoration on enamel subjected to a demineralization and remineralization model. Quintessence Int 1992;23:43-7.

24. Seppä L, Forss H. Resistance of occlusal fissures to remineralization after loss of glass ionomer sealants in vitro. J Clin Pediatr Dent 1991;13:39-42.

25. Seppä L, Forss H, Ogaard B. The effect of fluoride application on fluoride release and the antibacterial action of glass ionomers. J Dent Res 1993;72:1310-4.

26. Seppä L, Salmenkivi S, Forss H. Enamel and plaque fluoride following glass ionomer application in vivo. Caries Res 1992;26:340-4.

27. Tantbirojn D, Douglas WH, Versluis A. Inhibitive effect of a resin-modified glass-ionomer cement on remote enamel artificial caries. Caries Res 1997;31:275-80.

28. van Dijken J, Persson S, Sjöström S. Presence of Streptococcus mutans and Lactobacilli in saliva and on enamel, glass ionomer cement, and composite resin surfaces. Scand J Dent Res 1991;99:13-9.

29. van Dorp CS, ten Cate JM. Bonding of fissure sealant to etched demineralized enamel (lesions). Caries Res $1987 ; 21: 513-21$.

Received for publication on Apr 19, 2005

Sent for alterations on Oct 31, 2005

Accepted for publication on Feb 24, 2006

\section{ERRATA}

No volume 20, "Special Issue" I (abril, 2006), nas páginas 69 e 70, resumos TL022 e TL027, leia-se " $\mathrm{S}^{2}=\frac{\sum \mathrm{d}^{2}}{2 \mathrm{n}}$ " no lugar de "S2 = ?d2/2n". 